\title{
SHIFTING ALLIANCES: RECIPROCAL RELATIONSHIPS DURING TIMES OF ECONOMIC HARDSHIP IN URBAN BOLIVIA
}

\author{
ALIANZAS CAMBIANTES: RELACIONES RECÍPROCAS DURANTE \\ ÉPOCAS DE PRIVACIÓN ECONÓMICA EN BOLIVIA URBANO
}

\begin{abstract}
Amber Wutich ${ }^{1}$
Recent research indicates that urban reciprocity, a survival strategy used by the urban poor to self-insure against economic risks, has been eroded by deepening poverty and economic insecurity. This paper examines how the urban poor maintain reciprocal relationships in Villa Israel, a periurban settlement located on the outskirts of the city of Cochabamba, Bolivia. The results indicate that, while some reciprocal relationships do appear to be in decline, others have been transformed in ways that enhance security for participants. In particular, there appears to have been a shift away from reciprocal relationships formed on the basis of compadrazgo (ritual godparenthood) and "paisanidad" (shared origin) and toward those formed around commerce and evangélico (Protestant or evangelical) churches.
\end{abstract}

Key words: Reciprocity, urban, poverty, survival strategies, Cochabamba, Bolivia.

Esta investigación indica que la reciprocidad urbana, una estrategia de supervivencia usada por poblaciones de bajos recursos contra riesgos económicos, se ve debilitada por efecto de la pobreza extrema e inseguridad económica. Este artículo examina cómo la gente de bajos recursos mantiene relaciones recíprocas en Villa Israel, una comunidad periurbana en la ciudad de Cochabamba, Bolivia. Los resultados indican que, mientras que algunas relaciones recíprocas parecen estar en descenso, otras se han transformado para aumentar la seguridad de los participantes. Particularmente, se observa un cambio de las relaciones recíprocas formadas en torno al compadrazgo y la "paisanidad" (entre compueblanos) hacia relaciones formadas alrededor del comercio y de las iglesias evangélicas.

Palabras claves: reciprocidad, urbano, pobreza, estrategias de la supervivencia, Cochabamba, Bolivia.

During my fieldwork in Cochabamba, Bolivia, I was struck by how often people told me that, in times of need, "I could not ask anyone for help". This contrasts with accounts of the highly reciprocal nature of Andean society from the precolonial period (Murra et al. 1974) to contemporary times (Mayer 2004). However, these initial observations appeared to confirm recent findings that worsening economic conditions have eroded reciprocal relationships among the urban poor (González de la Rocha 2006). Based on ethnographic research conducted in 2004-2005, I argue that this phenomenon may involve not only the erosion of urban reciprocity, but also its transformation in response to deepening economic insecurity.

\section{Reciprocity and Urban Survival}

Reciprocity has been analyzed by anthropologists from two main perspectives. The older approach views reciprocity as the phenomenon underpinning all of human society, based on dyadic exchanges of goods, labor, ideas, and sentiment that form the building blocks of all social systems (Malinowski 1922; Mauss 1923). Another approach treats reciprocity more narrowly, as a system of economic exchange in which goods and services are given with the expectation that they will be returned later (Polanyi 1957; Sahlins 1972). Both of these perspectives are important ones, but when I discuss reciprocity in this paper it will be in the latter, more specific sense of the term (Lomnitz 1977).

Following Polanyi (1957), I define reciprocity as a form of exchange in which goods and services

1 School of Human Evolution and Social Change, Arizona State University, PO Box 872402, Tempe, AZ, 85287-2402, U.S.A amber.wutich@asu.edu 
are given with the expectation of future recompense. Reciprocity tends to emerge when people cannot independently store crucial resources, such as money or food (Wiessner 1982). Instead, they store social obligations that, over time, act as a kind of informal social insurance. Like all insurance, however, reciprocity functions only when risks are diversified (Cashdan 1985). When everyone is hit by scarcity at the same time, people hoard resources, avoid repaying debts, and reciprocal relationships disintegrate (Dirks 1980).

Anthropological theories of reciprocity were initially created and tested in rural settings. From the 1960s through the 1980s, anthropologists demonstrated that, in urban settings as well, the poor used reciprocity to obtain necessities like loans, job assistance, childcare, and help during crises like accident, illness, and fire (Isbell 1978; Lobo 1982; Lomnitz 1977). Reciprocity thrived because cities provided a variety of employment sources, which allowed people to invest in relationships when they were doing well economically and to rely on reciprocal partners when they needed help.

Recent evidence indicates that the economic crises of the 1980s and economic restructuring of the 1990s disrupted reciprocity among the urban poor. Opportunities to earn wages, intensify and diversify labor, and attain infrastructure disappeared during this period (Devereux 1999; Moser 1996). Periurban settlements were hit harder than urban centers because they lacked access to diminishing economic opportunities. Without income and assets to invest, households in Latin America, Africa, Asia, and Eastern Europe began to withdraw from reciprocal relationships (Devereux 1999; Frayne 2004; González de la Rocha 2001, 2006; Moser 1996).

To date, there have been few studies of reciprocity among the urban poor following the crises of the 1980s and 1990s. In this paper, I examine (1) what kinds of reciprocal relationships are maintained, (2) how active these reciprocal relationships are, and (3) what norms underlie these reciprocal relationships among the urban poor in Cochabamba, Bolivia.

\section{Bolivian Livelihoods}

With a history of colonial exploitation and dependence on a mining industry vulnerable to the boom-and-bust of mineral prices, Bolivia entered the economically tumultuous 1980 s facing significant economic challenges. In 1984, a devastating cycle of debt, trade deficits, and hyperinflation that crippled Bolivia's banks and markets led the government to enact a sweeping IMF-sponsored structural adjustment program (Nash 1992), which included deregulation, adoption of a floating exchange rate, and tax reform. The program also mandated the privatization and closure of national mines, leaving 27,000 miners unemployed (McFarren 1992; Nash 1992). Despite extensive grassroots opposition, outsiders considered the plan to be an astounding success when the Bolivian economy began to function again nearly immediately after its enactment (McFarren 1992). Then, in 1994, a new reform called "capitalization" privatized 50 percent of Bolivia's saleable national industries.

While privatization and capitalization did improve the performance of Bolivia's economy and national industries, it was a bitter disappointment for working-class Bolivians. Many industries suffered a net loss in jobs after capitalization; the Bolivian government also lost hundreds of millions of dollars in revenues (Kohl 2002). As a result, many Bolivians lost their social safety net in the 1980s and 1990s, including public services, income security, and market regulation of prices for essentials. With an economy that has become increasingly market-oriented and based in the informal sector ${ }^{1}$ (i.e., unregulated forms of self-employment, as defined by Hart 1973), people's survival is tied to their cash income. People in low-income periurban settlements often work in the informal market as vendors, maids, day laborers, and taxi drivers. Yet, with less disposable income circulating in the Bolivian economy, the middle classes have cut back on these goods and services (Gill 1994). Consequently, nearly 40 percent of the population in urban and periurban areas is impoverished (Instituto Nacional de Estadística de Bolivia [INE] 2004).

Despite the profound economic transformations that have occurred in Bolivia over recent decades, only a few studies in the city of El Alto have examined how the economic collapse of the 1980s and economic reforms of the 1990s reshaped reciprocal exchange among the urban poor. In the aftermath of the mine closures, McFarren (1992) documented how members of mining and neighborhood associations in El Alto pooled resources to create community kitchens and complete construction projects. Later, Gill (2000) found in El Alto that mutual help arrangements had emerged in new contexts, such as 
in evangelical churches. Compared with El Alto, very little research on urban reciprocity has been conducted in Cochabamba. However, there is some recent evidence that economic upheaval and inequity have caused widespread mistrust, anxieties about envy, and perceptions of community disunity in periurban Cochabamba (Goldstein 2002; Shakow 2005). In this context of deepening insecurity, it is not known to what extent residents of periurban Cochabamba can depend upon reciprocal exchanges to help them in their struggle to survive.

\section{Daily Survival in a Cochabamba Periurban Settlement}

Nestled in the southern foothills, far from the city center, Villa Israel is one of Cochabamba's last periurban settlements before the city gives way to barren, dusty mountain ridges. The community was settled, about 25 years ago, by an evangélico land prospector hailing from Huanuni, Oruro-a mining district perched in Bolivia's Andean highlands. Recruiting settlers through networks of contacts, the land prospector initially brought his own extended family, other Huanuni residents, and evangélicos from across highland Bolivia to live in Villa Israel. Quickly, however, a diverse populace learned of Villa Israel and came to live in the community.

Today, Villa Israel is a melting pot with approximately 2,000 residents. About 75 percent of adult residents were born in the countryside of Potosi, Cochabamba, Oruro, or La Paz. The rest were born in cities or mining towns. Nearly all Villa Israel residents are of indigenous descent. In addition to Spanish, most residents speak Quechua and/ or Aymara. While evangélicos are in the majority, nearly two-fifths of residents are Catholic. However, the political dominance of evangélicos, particularly those in the first wave of settlers, has facilitated the institutionalization of the evangélico social norms. For instance, dancing, fiestas (parties), the amplification of music, and the consumption of alcohol are considered social ills to be combated in monthly meetings of the community government. Additionally, the 14 evangélico churches in Villa Israel reinforce the social dominance of evangélicos. In contrast, the location of the nearest Catholic Church, which lies beyond Villa Israel's limits, adds to the political and social atomization of the large Catholic minority.

The most common sources of income in Villa Israel are two citywide transportation lines and
Cochabamba's central market. A taxi-trufi line and major bus line both terminate in Villa Israel. Many people work as taxi owners and drivers, and a few punch timecards and control the flow of vehicles. At the end points of the transport lines, women vie to sell sajra hora (mid-morning) meals, almuerzos (lunch), and snacks. A 30-minute taxi-trufi ride away, Cochabamba houses la cancha, one of South America's largest open air markets. Drawing vendors from across the country, la cancha teems with stalls, blanket displays, and wandering vendors. Villa Israel residents often sell fruit or vegetables, which they purchase each morning at a farmer's market, from blankets or wheelbarrows. Beyond transportation and market work, Villa Israel residents also work as day laborers, construction workers, laundresses, maids, food vendors, or in household industries like leatherworking, tailoring, weaving, cooking, or animal husbandry.

Villa Israel families that were dependent on low-income, unstable employment struggled financially. In 2004-2005, many housewives fed their families on less than 5 bolivianos (\$0.62) a day. About a tenth of households lacked food, water, or crucial medicines. Another quarter of households struggled to obtain basic necessities. Despite such poverty, Villa Israel was an economically mixed community. About half of the households had steady work; secure access to food and water; and investments in either a modest home or small business (e.g., vending fruit or snacks). Just over a tenth of households had a steady income, owned at least one residence, and had invested significant business capital (e.g., a taxi or corner store). The presence of economic need and diversity satisfies the preconditions for the emergence of reciprocal exchange. As a result, Villa Israel appeared to be an ideal site to examine reciprocal norms, relationships, and exchanges in the context of deepening economic insecurity.

\section{Methods}

The field research was conducted over 18 months in Villa Israel in 2004-2005. After five months of participant-observation, a random sample of households was selected to participate in five rounds of longitudinal ethnographic interviews conducted over 10 months. Of the 96 households contacted, 75 ( 78 percent) agreed to participate in the interviews. Over 340 interviews, 7,040 narratives 
about reciprocal exchange events were elicited. These narratives were analyzed using qualitative and quantitative techniques to benefit from the strengths of both approaches.

For the qualitative analysis, all reciprocal exchange events were categorized according to the type of social relationship that existed between the giver and recipient (based on native categories provided by the respondents). Results are presented for all reciprocal relationships nominated by $\geq 5$ percent of respondents. Following relationship classifications, the narratives were coded for deductive and inductive themes such as: content of exchange, economic status of giver and recipient, necessity of exchange for survival, obligation to reciprocate, affective aspects of the exchange, and history of the relationship. The analysis yielded broad themes that emerged across many narratives as well as trends that were particular to a subset of relationships or respondents.

For the quantitative analysis, Lomnitz's (1977) methods were reproduced to calculate (1) percent of respondents who conducted at least one reciprocal exchange in each relationship category and (2) the average number of weekly exchanges of food, goods, and labor conducted in each relationship category (see Wutich 2006 for details). Economic anthropologists commonly use statistics to make comparisons across categories of reciprocal exchange. In this case, the summary statistics facilitate comparisons regarding the prevalence and frequency of exchanges across reciprocal relationships in Villa Israel; they also facilitate comparisons between these results and past studies of urban reciprocity.

\section{Reciprocal Relationships}

\section{Vecino (neighbor)}

More households ( 89 percent) reported that they maintained reciprocal relationships with neighbors than any other relationship category. The number of exchanges conducted between neighbors was also high, an average of 3.40 exchanges over a weeklong period. As Sahlins (1972) explained, people are likely to develop reciprocal relationships with partners who are geographically close. This is due to the increased opportunity for exchanges and the relative ease of transporting resources short distances. However, respondents rarely discussed convenience, proximity, or portability when explaining why they maintained reciprocal relationships with their neighbors. Rather, they talked almost exclusively about the qualities and history of specific reciprocal relationships. As one impoverished elderly woman explained, in an economic crisis, "I would go to my next door neighbor because she has saved me many times before by offering me a bite to eat". Even so, not all respondents agreed that neighbors made good reciprocal partners. As one longtime resident said, "Here, people don't help you... If you ask them for help, they are likely to spread the news that you need help or be happy that you are in trouble. For that reason, I don't tell anything personal to anyone and I don't trust anyone". This idea-that neighbors are untrustworthy or ungenerous-emerged repeatedly. While envy and related social tensions are common in resource-poor societies with high levels of inequity (Foster 1972), several scholars have recently reported that mistrust, anxieties about envy, and perceptions of community disunity are particularly widespread in periurban Cochabamba (Goldstein 2002; Shakow 2005).

\section{Familia (family)}

Family was the second most commonly named relationship category (79 percent). The frequency of exchange between family members was higher than any other category, on average 7.37 exchanges per week. In many families, mutually-advantageous transfers of goods and services were conducted regularly, ensuring that reciprocal relationships were mutually beneficial. The case of two adult sisters is illustrative. Each day, the elder sister babysat the younger sister's children; in return, the younger sister helped the elder in her leatherworking business. Such exchanges often thrive among kin because needs are diversified across the life course (e.g., Hawkes et al. 1998). Even under extreme conditions of scarcity, kin are rarely abandoned (Dirks 1980). Respondents clearly perceived that kin-based reciprocal relationships were among the most resilient in Villa Israel. As one member of a large family explained, in times of need "my family would come to ask me for help, and I would help them. If I needed help, I would go to my family". Even when respondents preferred to avoid reciprocal exchanges with family members, they felt unable to refuse requests for help. For example, one woman had a very contentious relationship with her inlaws. She reported that, "I would not want to help my mother-in-law or sister-in-law, but I would feel 
obliged to". On the other hand, family members' inability to refuse requests enhanced the wellbeing of economically-insecure relatives. As a young mother, who lived nearby her parents, explained: "I would never hesitate to borrow or take what I need from my mother, because no matter what happens, she is my mamá and she has to help me". The strong social obligation to help family helps explain why people maintained these reciprocal relationships even when it is not economically advantageous in the short term.

\section{Cliente/comerciante (client/vendor)}

Just over half of household heads (53 percent) reported that they conducted reciprocal relationships in client/vendor relationships. Vendors included proprietors of corner stores, fruit peddlers, and owners of snack stands. On average, respondents conducted .90 reciprocal exchanges per week. The prevalence of commerce-based reciprocal relationships in Villa Israel is unexpected because few, if any, studies of urban reciprocity have found that these relationships play a significant role in urban survival. One exception is Peattie's (1970) finding that, in a Venezuelan barrio, people paid for favors as a way to avoid creating reciprocal debts. In Villa Israel, people turned this tactic on its head, and used commercial relationships to build reciprocal ones. For example, the owners of a restaurant and a corner store engaged in active exchanges of prepared food and raw ingredients. As the restaurant owner explained, "There is only one person I always go to for help," the store owner, because "we trust each other". There appeared to be three main reasons people maintained reciprocal relationships with commercial partners. First, vendors' commercial inventory made them ideal targets for reciprocal requests. As one woman explained, when she needs to borrow something, "The first thing I do is go to [a local businesswoman] because I know that my neighbors will be in worse shape than she is and they won't have so many things to loan as she will'. Second, business owners had an economic interest in creating reciprocal partnerships by extending loans or credit to clients. In exchange for the goods or help that vendors provided, clients reciprocated with information and gossip, customer loyalty, and payments in cash or kind. Third, clients could repay vendors' favors with money alone if they chose, and no longstanding social obligation would be created.
A member of a large extended household explained, "I only borrow from the store because I know thatno matter how or when-I can pay them back and I won't owe any favors to anyone". In this way, a reciprocal relationship can easily be reconverted into a business relationship if things go sour. In contrast, social debts owed to noncommercial partners were more burdensome and difficult to cancel.

\section{Compañero de la iglesia (coreligionist)}

Coreligionists were named by 36 percent of respondents as reciprocal partners. On average, coreligionists conducted 1.88 exchanges each week. Many of these exchanges were conducted between evangélicos, as the absence of a Catholic church in Villa Israel made it difficult for Catholics to make and maintain coreligionist relationships. In Villa Israel, evangélico coreligionists provided each other with services ranging from monetary loans to meals, to family counseling. Evangélicos felt a strong social obligation to help coreligionists. Several people reported that they assist troubled coparishioners, such as "the poorest members of my church" or "a good woman whose husband left her with three children", because they are most familiar with their needs. One devout evangélico explained, "I give preference to the people from my church" when choosing who to help. Similarly, many respondents felt that they could rely on coreligionists for help. As an evangélica recounted, members of her church donated money and food after her husband had a serious accident. Another evangélico provided a window into the evangélico philosophy of reciprocity: "[helping] is why churches were created and they have no other reason to exist". Reciprocal relationships between evangélicos appeared to be based on a charity model, in which the church mobilized groups of churchgoers to make contributions to those who were neediest. In this model, reciprocal obligations were incurred by coreligionists as a group, rather than by a specific reciprocal partner. As a result, larger and more diverse sets of reciprocal partners were available to the needy at any given time. Yet, this also meant that contributors did not maintain longstanding reciprocal relationships with specific partners; contributors could not tally debts and request recompense when they felt they needed it. Thus, while this charity-oriented model of reciprocal exchange enhanced the robustness of the group to risk, individuals often lacked specific 
reciprocal partners on whom they could personally depend for help in times of need.

\section{Amigo (friend)}

Friends were named by 31 percent of respondents. On average, people conducted .58 exchanges with friends over a weeklong period. To explain when a friend makes a good reciprocal partner, several people mentioned the importance of confianza (trust). Like Lomnitz (1977), I found that confianza flourished when reciprocal partners built trust over repeated exchanges. Where there was a history of trust and reliability, respondents expressed confidence that reciprocal obligations would be fulfilled over time. Although women, men, and children all reported having reciprocal relationships with friends, these relationships played a more important role in men and children's lives. Many men reported that they maintained close friendships with members of their sports teams-usually soccer and, occasionally, basketball. Sports friends generally conducted exchanges of sports-related goods, such as soccer shoes, and foodstuff, such as aftergame snacks. Exchanges of instrumental foods for household survival were uncommon. For children, reciprocal relationships with friends played a much more important role in day-to-day wellbeing. The children we interviewed (aged 11-19) were primarily responsible for the maintenance of the household (e.g., cooking, cleaning, and buying goods). The adults in the household were infirm, working up to 18 hours a day, or simply had abandoned the children. In the case of a 15-year-old girl, a friendship helped her survive after both of her parents deserted her. In the period immediately following the desertion, a friend provided the girl with three meals a day until she was able to obtain a job. In return, the girl helped her friend with cooking and other house chores. These results indicate that friends were important sources of subsistence-oriented support during youth and early adulthood, but waned in importance as people married, had their own families, and built relationships in structured social contexts (e.g., church or work).

\section{Inquilino/dueño de casa (renter/landlord)}

Respondents named renters or landlords as reciprocal partners in 28 percent of households. This is a remarkably high percentage, as less than half of Villa Israel households contained renters. On average, respondents reported that they conducted 1.34 reciprocal exchanges with renters/landlords each week. In some households, landlords and renters lived on the same property and maintained very active reciprocal relationships. In one case, a landlord and her renters conducted frequent exchanges of food, small cash loans, cleaning products, and dishes. They also conducted regular labor exchanges, such as washing or mending clothes. More often, reciprocal relationships between landlords and renters were asymmetrical; landlords had access to surplus goods while renters had surplus labor. In such cases, landlords gave their renters small gifts, such as a bucket of water, a bag of potatoes, or a plate of cooked food. In return, renters provided landlords with free childcare or caretaking of the house. Several landlords said they felt responsible for helping less fortunate renters. As one landlord explained, when she has something to give "I think first of my family, and then of my renters". Some landlords also reported they could rely on their renters for assistance. The landlord who maintained the active reciprocal relationship with her renters, mentioned above, said, "If I really needed help, I would ask my renters". The renter/landlord relationship appeared to resemble both neighbor and client/vendor relationships in important ways. Like neighbors, renters and landlords often live close together; proximity, convenience and the opportunity to build trust over time increase the likelihood that reciprocal relationships will emerge. Like client/vendors, renters and landlords tend to offer each other complementary resources; this increases the likelihood that the relationships will fulfill crucial needs for both partners. Together, these qualities make the renter/landlord relationship a particularly fruitful one for maintaining reciprocal partnerships.

\section{Compañero de trabajo (coworker)}

Coworkers were named by 16 percent of respondents as reciprocal partners. On average, respondents conducted 1.13 reciprocal exchanges with coworkers each week. Coworkers in Villa Israel maintain reciprocal relationships in workplaces as diverse as taxi and bus routes, food stands, vending stalls, and construction sites. This was especially visible among female construction workers in state funded PLANE (National Plan for Emergency 
Employment) construction sites. Women worked in small cooperative groups, sharing shovels or picks and helping each other carry heavy loads. At break time, everyone brought a small tin (containing boiled potatoes, rice, noodles, and occasionally a fried egg), emptied their tins onto a tarp, and ate with spoons from the shared mound of food. Another example of reciprocity in the workplace was among vendors at food stands and the Sunday market's vending stalls. When a sale depended on having the right change, vendors lent each other coins and small bills; such exchanges were often conducted numerous times each day. Additionally, vendors sometimes lent each other spoons, plastic bags, or other small items needed to close a sale. Reciprocity thrived among coworkers because limited work-related needs (e.g., the need to make change or borrow a tool) were diversified among workers. It is important to note that, outside of the workplace, reciprocity between coworkers was quite rare. I occasionally documented cases in which the PLANE women helped out their coworkers during a difficult time-such as when a mother of several small children was abandoned by her husband-but this was unusual. As a result, coworker reciprocity played a relatively small role in the overall picture of the diversification of risk and urban survival in Villa Israel.

\section{Empleado/empleador (employee/employer)}

Reciprocal relationships between employees and employers were named by 16 percent of respondents. In Villa Israel, employers hired employees to work in home based industries such as bakeries, leatherwork shops, restaurants, or chicherías (corn beer bars). Some families employed construction workers, laundresses, or other domestic helpers. On average, respondents conducted 1.13 exchanges per week with employees/employers. In most cases, these exchange relationships were not built on strong foundations of mutual affection. Rather, employers provided their employees with occasional gifts (e.g., meals or surplus work materials) or loans (e.g., work tools), often with the goal of motivating work or gaining loyalty. In return, employees helped their employers with extra tasks-beyond their work responsibilities-such as home repairs or childcare. In a few instances, employers and employees formed more lasting reciprocal relationships strengthened by emotional bonds. Such was the case of a mother of three whose husband was working abroad. To assist in the care of her disabled son, she hired an 11-year-old girl to work as a live in helper. In addition to paying wages, meals, and school fees, the woman bought the girl small gifts. The girl's mother and sister, who lived nearby, often visited the girl and helped with her work. The two families cooked together, shared meals, and grew close. Like renter/landlord relationships, employee/employer relationships had the potential to foster strong reciprocal bonds via close proximity, frequent contact, and the access to complementary resources (goods v. labor). Because relationships between employers and employees were often perceived as tense or even exploitative, however, this potential was rarely realized.

\section{Compañero de la junta vecinal (neighborhood committee)}

Respondents named comembers of a neighborhood committee in 16 percent of households. Neighborhood committees included local governance bodies such as the Villa Israel town council, water committee, school committee, and market committee. Typically community members attended one or more monthly committee meetings. On average, respondents reported that they conducted .25 exchanges per week with comembers of a neighborhood committee, generally during committee meetings. For instance, the monthly meeting of the town council is conducted in an open-air venue in the center of the community. Typically, women sat together and knitted while sharing a bag of pasankalla (puffed cereals). In other cases, community delegates treated each other to beverages or meals during trips downtown to meet with city bureaucrats, lobby the city government, or attend protests. On a few occasions, community members gave donations (e.g., a bottle of cola or bucket of water) to support of the volunteers' work. Despite the existence of reciprocity within neighborhood-based organizations, these exchanges were not as active as has been found in past ethnographies of squatter settlements (e.g., Isbell 1978; Lobo 1982). For instance, Goldstein's (2004) ethnography of Villa Pagador, another settlement in periurban Cochabamba, documents how community members shared labor and goods at the community's inception. Yet Mangin (1967) argued that an early period of high cooperation is part of the normal "life cycle" of a squatter settlement; such interactions generally drop off 
once the community is settled. Villa Israel residents conduct a small but steady number of reciprocal exchanges between comembers of neighborhood committees, as would be expected of a community settled over 20 years ago.

\section{Padrino/ahijado (godparent/godchild)}

Reciprocal relationships between godparents and godchildren, or compadrazgo (ritual godparenthood) relationships, were named by 12 percent of respondents. On average, people conducted .34 exchanges within compadrazgo relationships per week. In Villa Israel, exchange relationships between godparents/godchildren were neither particularly common nor active. This is surprising because godparenthood has historically provided a highly efficient means to diversify risk across Latin American communities by linking together high and low status families in reciprocal relationships (Mintz and Wolf 1950). As such, compadrazgo relationships might be expected to play an important role in urban survival in Villa Israel. However, community members avoided nonbaptismal expressions of this practice, such as naming a godparent of the first haircutting or matrimony. In 18 months in Villa Israel, I was unable to document even one case in which a new godparenthood relationship was initiated between community members. The shift away from godparenthood is related to the broader trend of evangélico conversion among Villa Israel residents. Evangélico participants, in particular, often opined that naming godparents was a Catholic practice to be shunned. As Dow argues (2005), evangélicos have shifted major monetary investments in social relationships-and the celebrations required to initiate and maintain them-to saving and reinvesting family earnings in capitalistic enterprises. Despite this general trend, some respondents did report that they could draw on existing compadrazgo relationships for help. For instance, an infirm elderly woman relied on her nearby goddaughter for help with her small business, food, and companionship on a daily basis. More often, people said that they would draw on compadrazgo relationships for emergency help. One woman, who has no immediate relatives in Villa Israel, said "I would go to my godmother [if I needed help]. I wouldn't feel afraid to borrow anything, because I know that I would give it back". Although a number of people saw compadrazgo relationships as possible sources of help in an emergency, few maintained long-standing reciprocal exchange relationships with them or expressed a high degree of confidence that they could draw on such relationships during a crisis.

\section{Paisano or llajtamasi (countryman)}

Respondents named people from the same hometown or region as reciprocal partners in 7 percent of households. People conducted .11 exchanges per week, on average, with their countrymen. This low rate of reciprocal exchange is somewhat unexpected because a number of Andean ethnographies have documented the importance of this relationship for survival in squatter settlements. As Lobo (1982:55, 116) explained, in her study of a squatter settlement in Lima, Peru, paisano groupings were the basic social unit for reciprocal activities such as aid during economic crises, building community infrastructure, and providing social support. In Villa Israel, too, people often had migrated with paisanos. However, few reported that they maintained reciprocal relationships with countrymen. One reason paisano relations may be waning in Villa Israel is that they were historically strengthened via compadrazgo ties (Lobo 1982), a practice which is no longer common. An exception to this general trend was a family that maintained an active reciprocal relationship with a countrywoman, an elderly woman who lived alone in Villa Israel. During a normal week, the family's head of household went four times to visit the countrywoman. On some occasions she brought a meal, bread, or coca leaves. She also helped with the countrywoman's errands or chores. In return, the countrywoman provided the woman with tea and snacks, and visited with her. The woman reported on one such occasion that her visit with the countrywoman "was most fun I had all week". As in this relationship, the bulk of reciprocal exchanges conducted between countrymen were meals; these exchanges usually took place during social visits in which people reminisced or caught up on the news from home. It was uncommon for people to engage in instrumental exchanges of items they needed to survive with countrymen.

\section{Discussion}

The results of this study reveal several trends in the reciprocal relationships of the urban poor in Villa Israel. In comparison with past ethnographies 
of reciprocity among the Andean urban poor, reciprocity in compadrazgo and paisano relationships was not common. For compradazgo, there were two reasons why ritual godparenthood was waning: (1) the shift away from Catholicism and (2) the financial burdens involved. Historically, compadrazgo relationships were initiated as part of Catholic baptisms, weddings, and festivals. Due to evangélicos' aversion to Catholic beliefs and practices, compadrazgo had become uncommon in Villa Israel. Beyond this, compadrazgo typically requires expenditures on ritual meals, alcoholic beverages, and other luxury goods. These purchases are burdensome for families struggling to subsist. As a result, compadrazgo ties were generally mobilized only in emergencies. Because compadrazgo was used to strengthen paisano relationships, it is unsurprising that reciprocity between paisanos was also uncommon in Villa Israel. Unlike compadrazgo, however, paisano relations were maintained almost exclusively for companionship; reciprocal exchanges generally had a social-not instrumental-purpose. It is noteworthy that elderly women were the main beneficiaries of reciprocal exchanges in compadrazgo and paisano relationships. This underscores that these are antiquated and increasingly uncommon strategies in Villa Israel.

Although some reciprocal institutions were declining, there were vibrant reciprocal relationships in Villa Israel. These included family, neighbors, commercial partners, evangélicos, and friends. Reciprocal relationships conducted between commercial partners (vendor/client, renter/landlord, and employee/employer) were particularly common. In these market-centered exchanges, people seek out partners whose access to resources complements their own. Commerce-based reciprocal relationships are similar to the patron-client relationships of rural Peru (Mayer 2004). Like the patron-client relations, commercial relationships often involved economic inequality, low trust, and exploitation. However, unlike patron-client relations, commercial relations in Villa Israel were embedded in market transactions and were easily severed. As a result, the embedment of reciprocal exchange within commercial partnerships is a particularly effective strategy for pooling risk. In a context of rising distrust, insecurity, and anxiety, commercial relationships are also advantageous because people can divest more easily than relationships based on ritual ties, high trust, or longstanding relationships.
Reciprocal relationships were common between evangélicos. While few in Villa Israel talked about religiosity in economic terms, the material benefits that evangélico churches offer may be one of the primary motivations for the wave of evangélico conversions that swept Latin America over the last 25 years (Bomann 1999; Stoll 1993). This is because evangélico churches eschew costly ritual obligations (including fiestas with music amplification, meals, and alcohol expenditures) that are common in Latin American Catholicism (Dow 2005) and offer converts the promise of material assistance (Gill 2000). To date, little is known about how or why the urban poor are using evangélico churches to reshape reciprocal institutions. The results from Villa Israel suggest that, while reciprocity among evangélicos does give participants access to a diverse group of reciprocal partners, the charity model of reciprocity stymies the creation of strong interpersonal reciprocal relationships and obligations. Even so, reciprocity among evangélicos appears to have important implications for urban survival. The nature of reciprocity between evangélicos -and differences between reciprocal practices associated with evangélico and Catholic churches- will be an important area for future research if the trend of evangélico conversions continues in Latin America.

In a climate of economic upheaval, it is important to recognize that some reciprocal relationships did perform as expected. Family members conducted reciprocal exchanges more frequently than any other relationship category. This is likely because family members' risks and needs are diversified over the life span-and because there is a very strong social obligation to help family members even when doing so is economically disadvantageous. Reciprocal exchanges were most common between neighbors because of proximity and, in some cases, trust built over time. Friends were also named as reciprocal partners by a large minority of community members. While confianza was important for the maintenance of these relationships, gender and age also shaped when and how reciprocal exchanges were conducted between friends. Reciprocal relationships were frequently conducted between coworkers; however, these exchanges were generally focused on workplace productivity rather than household survival. Finally, reciprocal relationships in neighborhood committees were uncommon; this is likely normal for a periurban settlement past its highly cooperative community-building stages. The results demonstrate 
the resilience of some reciprocal relationships, but also the ways in which reciprocity is transformed in response to deepening economic insecurity.

\section{Conclusion}

This research indicates that, given the economic constraints associated with the Bolivian economy after the economic crises of the 1980s and the economic restructuring of the 1990s, the urban poor are shifting their reciprocal investments into relationships that pool risks more effectively. In Villa Israel, these new reciprocal relationships tend to be ones that are unencumbered by ritual obligations, require fewer resource investments, and are less enduring. The results of another recent study, conducted in Namibia, also indicate that impoverished urban migrants are recasting reciprocal commitments in ways that pool risk more efficiently-now eschewing reciprocal relationships with nearby neighbors and preferring instead to invest in reciprocal relationships with distant rural households (Frayne 2004). These findings indicate the need for more comparative, longitudinal, and processual research on the effects of deepening poverty and economic insecurity on reciprocity. Just as rigorous fieldwork once disproved the idea that reciprocal relationships cannot thrive in urban settings, more ethnographic data leads us to reconsider the idea that deepening insecurity among the urban poor has precipitated the demise of urban reciprocity. The economic transformations of the last 30 years have, without a doubt, undermined familiar configurations of reciprocal exchange among the urban poor. However, as González de la Rocha (2006) has argued, we are just beginning to understand how large scale globalization and economic transformations are changing local survival strategies. The results of this study indicate that new reciprocal exchange strategies are developing in unexpected contexts, such as between commercial partners (e.g., vendor/client and landlord/renter) and around charitable groups organized by Evangelical churches. Such findings have important implications both for academic research on Andean reciprocity and for practitioners who seek novel approaches to distributing aid and strengthening local survival strategies among the urban poor.

Acknowledgements: This study was supported by the National Science Foundation (Award BCS0314395), Fulbright-IIE, the Tinker Foundation, Paul and Polly Doughty, and the University of Florida Center for Latin American Studies. I am grateful to my Bolivian colleagues Wilda Valencia, Richard Aguilar, Wilfredo Valencia, and Dominga Choque, the people of Villa Israel, the journal editors, and two anonymous reviewers for their assistance with this research.

\section{References Cited}

Bomann, R.P.

1999 Faith in the Barrios: The Pentecostal Poor in Bogota. Lynne Rienner Publishers, Boulder.

Cashdan, E.

1985 Coping with risk: Reciprocity among the Basarwa of Northern Botswana. Man 20(3):454-474.

Devereux, S.

1999 'Making Less Last Longer': Informal Safety Nets in Malawi. IDS Discussion Paper 373, pp. 1-75. Institute of Development Studies, Brighton.

Dirks, R.

1980 Social responses during severe food shortages and famine. Current Anthropology 21(1):21-44.

Dow, J.

2005 The expansion of Protestantism in Mexico: An anthropological view. Anthropological Quarterly 78(4):827-850.

Foster, M.

1972 The anatomy of envy: A study in symbolic behavior. Current Anthropology 13 (2):165-202.

Frayne, B.

2004 Migration and urban survival strategies in Windhoek, Namibia. Geoforum 35:489-505.
Gill, L

1994 Precarious Dependencies: Gender, Class, and Domestic Service in Bolivia. Columbia University Press, New York.

2000 Teetering on the Rim: GlobalRrestructuring, Daily Life, and the Armed Retreat of the Bolivian State. Columbia University Press, New York.

Goldstein, D.

2002 Desconfianza and problems of representation in urban ethnography. Anthropological Quarterly 75:485-517.

2004 The Spectacular City: Violence and Performance in Urban Bolivia. Duke University Press, Durham.

González de la Rocha, M.

2001 From the resources of poverty to the poverty of resources? The erosion of a survival model. Latin American Perspectives 28(4):72-100.

2006 Vanishing assets: Cumulative disadvantage among the urban poor. Annals of the American Academy of Political and Social Science 606:68-94.

Hart, K.

1973 Informal Income Opportunities and Urban Employment in Ghana. Journal of Modern African Studies 11:61-89. 
Hawkes, K., J.F. O’Connell, N.G. Blurton Jones, H. Alvarez, and E.L. Charnov

1998 Grandmothering, menopause, and the evolution of human life histories. Proceedings of the National Academy of Sciences 95:1336-1339.

Instituto Nacional de Estadística de Bolivia (INE)

2004 Bolivia: Mapa de Pobreza 2001. Censo Nacional de Población y Vivienda 2001, La Paz.

Isbell, B.J.

1978 To Defend Ourselves: Ecology and Ritual in an Andean Village. Waveland Press, Prospect Heights.

Kohl, B.

2002 Stabilizing neoliberalism in Bolivia: Popular participation and privatization. Political Geography 21:449-472.

Library of Congress

2005 Country Profile: Bolivia. Library of Congress, Washington, D.C. Lobo, $\mathrm{S}$.

1982 A House of My Own: Social Organization in the Squatter Settlements of Lima, Peru. The University of Arizona Press, Tucson.

Lomnitz, L.

1977 Networks and Marginality: Life in a Mexican Shantytown. Academic Press, New York.

Malinowski, B.

1922 Argonauts of the Western Pacific. London: Routledge.

Mangin, W.

1967 Latin American squatter settlements: A problem and a solution. Latin American Research Review 2(3):65-98.

Mauss, $\mathrm{M}$.

1923 The Gift. The Form and Reason for Exchange in Archaic Societies. Routledge, London.

Mayer, E.

2004 The Articulated Peasant: Household Economies in the Andes. Westview Press, Boulder.

McFarren, W.

1992 The politics of Bolivia's economic crisis: Survival strategies of displaced tin-mining households. In Unequal Burden: Economic Crises, Persistent Poverty, and Women's Work, edited by L. Beneria and S. Feldman, pp. 131-158. Westview Press, Boulder.

Mintz, S., and E. Wolf

1950 An analysis of ritual co-parenthood (compadrazgo). Southwestern Journal of Anthropology 6:341-368.
Moser, C.

1996 Confronting Crisis: A Comparative Study of Household Responses to Poverty and Vulnerability in Four Poor Urban Communities. Environmentally Sustainable Development Studies and Monographs Series No. 8. The World Bank, Washington, D.C.

Murra, J.V., A. Fioravan, G. Duby, C. Meillass, M. Auge, J.P. Chretien, M. Godelier, and P. Veyne

1974 In favor of anthropologic history -notion of reciprocity- debate. Annales-Economies Societes Civilisations 29(6):1358-1380.

Nash, J.

1992 Interpreting social movements: Bolivian resistance to economic conditions imposed by the International Monetary Fund. American Ethnologist 19(2):275-293.

Peattie, L.R.

1970 The View from the Barrio. University of Michigan Press, Ann Arbor.

Polanyi, K.

1957 The economy as instituted process. In Trade and Market in the Early Empires, edited by K. Polanyi, C. Arensberg, and H. Pearson, pp. 243-270. Free Press, Glencoe.

Sahlins, M.

1972 Stone Age Economics. Tavistock, London.

Shakow, M.

2005 The political life of envy: Inequality and decentralization in neoliberal Bolivia. Presented at the American Ethnological Society Annual Meeting, San Diego.

Stoll, D.

1993 Introduction: Rethinking Protestantism in Latin America. In Rethinking Protestantism in Latin America, edited by V. Garrard-Burnett, and D. Stoll, pp. 1-19. Temple University Press, Philadelphia.

Wiessner, P.

1982 Risk, reciprocity, and social influences on !Kung San economics. In Politics and History in Band Societies, edited by E. Leacock and R. Lee, pp. 61-84. Cambridge University Press, Cambridge.

Wutich, A.

2006 The Effects of Urban Water Scarcity on Reciprocity and Sociability in Cochabamba, Bolivia. Doctoral Dissertation, Department of Anthropology, University of Florida, Gainesville.

\section{Note}

1 While some readers may be interested in the role of the coca economy in my discussion of informal economy, I have empirical and ethical reasons for excluding this issue from the paper. Empirically, the city of Cochabamba is not a major site for coca cultivation, although coca is cultivated legally in the lowland tropical regions of the department of Cochabamba. From an ethical standpoint, respondents specifically asked that I not broach this issue, as it is a very sensitive one (particularly for a U.S.-funded researcher given the U.S. War on Drugs and its deleterious effect on Bolivians). In deference to the informed consent agreements made with these respondents, I feel obligated to exclude discussion of the coca economy from my publications. 
